\title{
The Study of the Relationship of Conditional Conservatism for the Market-to-Book Ratio and Tobin's Q
}

\author{
Abdolkarim Moghadam1, Mehran Rahimi2* \\ ${ }^{1}$ Department of Accounting, Payame Noor University (PNU), Garmsar, Iran \\ ${ }^{2}$ Young Researchers and Elite Club, Sardasht (Mahabad) Branch, Islamic Azad University, Sardasht (Mahabad), \\ Iran \\ Email:m.rahimi.uk@gmail.com
}

Received 9 May 2016; accepted 12 June 2016; published 16 June 2016

Copyright (C) 2016 by authors and Scientific Research Publishing Inc.

This work is licensed under the Creative Commons Attribution International License (CC BY). http://creativecommons.org/licenses/by/4.0/

(c) (i) Open Access

\section{Abstract}

This study evaluated the relationship between market-to-book ratio and Tobin's $Q$ and accounting conservatism. An important factor in adopting conservative approaches is the increased competitive pressures. Nevertheless, conservative approach reduces expectations of future performance of the businesses. This study used the data from companies listed in TSE during 2008 to 2013. Basu's model was used to assess conditional conservatism. To evaluate the effect of market-to-book ratio and Tobin's $Q$ on conditional conservatism, these variables were added to Basu's model. The tests showed a negative significant relationship between Tobin's $Q$ and conditional conservatism. However, the results showed no significant relationship between market-to-book ratio and conditional conservatism.

\section{Keywords}

\section{Market-to-Book Ratio, Tobin's Q, Conditional Conservatism}

\section{Introduction}

Investors constantly and uniformly use accounting information without modifying in terms of changes in accounting methods or considering its calculation. In financial literature, the price-to-book ratio is the most important indicator to measure the value and future opportunities of the firm. Management is motivated to stabilize the profit growth by non-conservative procedures; this raises future expectation. Thus, detection of conservatism and relevant evaluations as well as its effect on expectations of investors can provide investors and analysts with 
a useful tool [1]. Accounting conservatism refers to different verifiability of good and bad news. Good news is the positive return on stocks or events which lead to increased profits. Bad news is zero or negative return which reduces profit. Thus, conservatism is defined as a procedure to reduce profits and underestimate assets in response to bad news and, conversely, to increase profits and overestimate assets in response to good news. Conservatism results from asymmetric requirements for recognition of profits and losses in financial statements by which accountants recognize and reflect economic losses relative to profits in a timely manner [2]. Tobin's Q has been always considered by investors and analysts as an investment measure. Tobin's Q is based on accounting data and market information. Many believe that Tobin's $Q$ is the best measure for performance and value of the firm. The main objective of this study is to examine the relationship between investment, inventory and capital expenditure for companies listed in Tehran Stock Exchange (TSE).

\subsection{Theoretical Background}

Conservatism can be defined as a tendency of accounting to require a higher degree of verifiability for recognizing good news compared to verifiability for recognizing bad news in terms of flexibility of generally accepted accounting principles [1] [2]. Conservatism depends on many factors, including a contract between the business and other stakeholders, the possible formation of lawsuits, efforts to reduce or postpone tax, public interest, enhanced quality of financial information, reduced political costs, reduced information asymmetry and level of competition. Competitive pressures will lead to increased conservatism. Companies use conservatism in their financial reports to prevent the entry of new competitors into the industry and to prevent the disclosure of confidential information to existing competitors [3] [4]. In fact, conservatism results from ambiguity. Accountants use conservatism when they encounter ambiguity. The purpose of conservatism is to prevent incorrect decisions by investors and other users of financial statements [5]. Demand for conservatism results from various sources. According to Basu (1997), debtors and other creditors demand more timely information about bad news compared to good news. The tendency to accelerate the recognition of losses and postpone the recognition of profits represents the conservative approach to profits and losses. Accordingly, Basu (1997) proposed the asymmetric timeliness of earnings. There are four measures known for conservatism, including asymmetric timeliness in recognition of profits and losses; accrual-based conservatism; negative skeins of profit distribution and cash flows; and conservatism based on market value. Any network in which goods and services are purchased is called market. Competitive market refers to a market where many buyers and many informed sellers act ineffectively on price level [6]. In a competitive market, companies have to use those methods of production with the lowest cost and the highest efficiency to provide the consumer with a better quality and lower price. Under normal conditions, competitive market involves competition for preventing the entry of new competitors to the industry and competition between firms in an industry. Usually, the most important measure of performance is rate of return, which contains information content for investors and it is used to evaluate performance. Reduced rate of return is a warning for the firm, representing poor performance. Rate of return contains considerable information content, because performance evaluation based on market value reflects information of investor. Return is a driving force which motivates and rewards investors.

In an efficient market, stock prices are determined in the stock market through intersection of supply and demand. In fact, there is no specific rule to express the behavior of stock prices; however, there are several factors which influence the changes in stock price. These factors include fundamental variables, technical variables and emotional variables. Tobin's Q is based on accounting information and market information; many authors know Tobin's Q as the best criterion for measuring performance and value of the firm. Decisions regarding investment involve three important problems including expectations, delays and risks. It has not been easy for economists to address these three problems simultaneously. Tobin's Q solves these problems by data from financial markets.

Ahmed et al. (2002) found that large companies use more conservative accounting methods than other company's do [7]. Mehrani et al. (2009) examined the relationship between firm size and debt contracts and conservativism. They used the share of accrual-based and market based content as well as the relationship between stock returns and profits to measure conservatism [7]. Badavrnahandi (2011) used the Basu (1997) and Roychowdhury and Watts (2007) models to examine the relationship between institutional ownership, concentration of ownership and independence of board members as mechanisms for corporate governance and conservatism [8] [9]. 


\subsection{Population, Sample and Hypotheses}

The target population included all companies listed in TSE from March 20, 2008 to March 20, 2014. The sample was classified by screening sampling. The hypotheses included:

1) There was a relationship between accounting conservatism and Tobin's Q.

2) There was a relationship between accounting conservatism and market-to-book ratio.

\section{Material and Methods}

This study involves capital market using real data related to the companies listed in TSE. The methodology of this study is applied method to develop practical knowledge on a certain subject. On the other hand, this study examined the relationship between conservatism correction and market-to-book ratio and Tobin's Q; thus, the causal correlation was used for the study. The independent variable was qualitative and the dependent variable was quantitative. Moreover, this study observes the phenomena.

Information required for literature review was extracted from books, journals and articles available in internet (archival method). Data needed to test the hypotheses was gathered by referring to the Tehran Stock Exchange and using annual financial statements and explanatory notes of companies listed in TSR (including balance sheet, profit and loss), as well as TSE websites including www.irbourse.com, www.rdis.ir, www.codal.ir and www.tsetmc.com, reports of the board of directors and software packages such as Rahavard Novin, Tadbir Pardaz. This study used the t-student test for partial regression coefficients and Fisher (F) test for significance of regression model at 95\%. Data was analyzed by Excel, EVIEWS and SPSS.

\section{Results}

Table 1 summarizes the characteristics of the variables used in this study.

\subsection{Normality Test}

One of the assumptions of regression is the normal residuals of the regression model, which represents validity of the regression test. The normal distribution is examined by Kolmogorov-Smirnov test. The normality of dependent variables leads to the normal residuals. Therefore, it is essential to estimate the normality of the dependent variable before estimating parameters. Otherwise, it is essential to find a better solution for normalizing variables.

$$
\left\{\begin{array}{l}
H_{0} \text { : data of the dependent variable is normally distributed } \\
H_{1} \text { : data of the dependent variable is not normally distributed }
\end{array}\right.
$$

When $\mathrm{P}$ values $<5 \%$, the null hypothesis is rejected at $95 \%$ confidence level.

As shown in Table 2, the significant level of variables is $<0.05 \%$; therefore, $\mathrm{H}_{1}$ is true that the data is not normal. Data is normalized by Johnson Transformation function and Box-Cox software in Table 3.

As shown in Table 3, the significant level of Kolmogorov-Smirnov test is $>5 \%$, representing the normal distribution of variables.

Table 1. Descriptive data.

\begin{tabular}{cccccc}
\hline Variables & Measures & Mean & Maximum & Minimum & Standard deviation \\
\hline CON & 1.8174 & 0.0008 & 81.06 & -54.38 & 11.9898 \\
Q & 58.00 & 59.65 & 99.36 & -13.02 & 23.87 \\
MB & 1.66 & 1.54 & 3.50 & 0.58 & 15.93 \\
SIZE & 18.23 & 18.12 & 21.13 & 0.48 & 1.060 \\
LEV & 0.64 & 0.64 & 1.71 & 0.285 & 0.16 \\
\hline
\end{tabular}

CON: Conservatism; Q: Tobin’s Q; MB: market-to-book ratio; SIZE: firm size; LEV: Leverage. 
Table 2. Results of the Kolmogorov-Smirnov test.

\begin{tabular}{ccc}
\hline Dependent variable & Kolmogorov-Smirnov test & Sig. \\
\hline CON & 0.091 & 0.000 \\
\hline
\end{tabular}

Table 3. Results of normality test for data after normalizing data.

\begin{tabular}{ccc}
\hline Dependent variable & Kolmogorov-Smirnov test & Sig. \\
\hline CON & 0.041 & 0.077 \\
\hline
\end{tabular}

\subsection{Correlation Analysis}

Correlation is a measure used to determine the relationship between two variables. In this study, the Pearson correlation coefficient was used to examine the correlation between variables. Pearson correlation coefficient always ranges from +1 and -1 . The closer coefficient to +1 indicates the higher direct correlation between two variables; the closer coefficient to -1 indicates the higher inverse correlation between variables.

As shown in Table 4, the coefficient of correlation between variables shows that the correlation is low, indicating a correlation between these variables to influence the results of regression analysis. There is no sharp co linearity between independent variables and controls.

\subsection{First Hypothesis}

The first hypothesis assumes a significant relationship between conservatism and Tobin's Q. The F-Limer test and Hausman test were conducted to choose the best method to estimate the model. The results are listed in Table 5 .

$$
C O N_{\text {i.t. }}=\alpha_{0}+\alpha_{1} Q_{i . t}+\alpha_{2} S I Z E_{i . t}+\alpha_{3} L E V_{i . t}+\varepsilon_{i . t}
$$

As shown in Table 5, the results reject $\mathrm{H}_{0}$ and support the panel data with fixed effects model, because the acceptable significance level is $5 \%$. The Hausman test shows that $\mathrm{H}_{1}$ is accepted; therefore, the used estimation method is panel data with fixed effects. The results are presented in Table 6 .

According to F-value (2.32), results listed in Table 6 show a relationship between independent variables and the dependent variable at 95\% confidence level. Independent variables explain 33\% variations in the dependent variable. According to the value of Durbin-Watson test (2.29), there is no first-order auto-regression between residual terms. The first hypothesis examines the relationship between conservatism and Tobin's Q. According to the results listed in Table 6, the variable coefficient of Tobin's Q is equal to -0.004 ; its significant level (0.000) is $<0.05$. Thus, the first hypothesis is supported.

\subsection{Second Hypothesis}

A three-variable model was used to test the second hypothesis.

$$
C O N_{i . t}=\alpha_{0}+\alpha_{1} M B_{i . t}+\alpha_{2} S I Z E_{i . t}+\alpha_{3} L E V_{i . t}+\varepsilon_{i . t}
$$

To find the considered model among panel data, fixed effects or random effects model, the relevant tests were used in the next section; finally, the considered model can be used to estimate the model in order to test the hypothesis. According to F-test, $\mathrm{H}_{0}$ implies panel data; therefore, ordinary least squares method was used to estimate the model. The rejected $\mathrm{H}_{0}$ implies fixed effects model; therefore, the ordinary least squares method was used by dummy variable.

Results of the F-Limer test as shown in Table 7 reject the $\mathrm{H}_{0}$ and support the fixed effect model. The Hausman test was used to choose between fixed effect model and random effect model. According to Hausman test, $\mathrm{H}_{0}$ implies the random effects model, and rejected $\mathrm{H}_{0}$ implies the fixed effect model and random effect model is rejected. Therefore, $\mathrm{H}_{0}$ can be rejected and the final model is fixed effects model.

Results listed in Table 8 shows no significant relationship between conservatism and market-to-book ratio. As its level of significant (0.404) is 0.05 , this hypothesis is not supported at 0.95 confidence level. The coefficient of determination indicates that $67 \%$ of variations in conservatism can be explained by market-to-book ratio 
Table 4. Coefficient of correlation between variables.

\begin{tabular}{|c|c|c|c|c|c|}
\hline $\begin{array}{l}\text { Correlation } \\
\text { Probability }\end{array}$ & CON & $\mathrm{Q}$ & MB & SIZE & LEV \\
\hline $\mathrm{CON}$ & 1 & & & & \\
\hline $\mathrm{Q}$ & $-0.615^{* *}$ & 1 & & & \\
\hline MB & 0.0026 & -0.058 & 1 & & \\
\hline SIZE & -0.053 & -0.020 & 0.024 & 1 & \\
\hline LEV & -0.042 & 0.001 & $0.042^{*}$ & $-0.201^{* *}$ & 1 \\
\hline
\end{tabular}

${ }^{*}$ And ${ }^{* *}$ represents significance at $1 \%$ and $5 \%$ significant, respectively.

Table 5. Results of the tests.

\begin{tabular}{cccc}
\hline Test & Value & Sig. & Result \\
\hline F-test Limer & 1.967 & 0.000 & Panel data with fixed effects \\
Hausman test & 1.153 & 0.007 & Panel data with fixed effects \\
\hline
\end{tabular}

Source: calculations of study.

Table 6. Results for the first hypothesis.

\begin{tabular}{cccc}
\hline & Model 1: & $\operatorname{CON}_{\mathrm{i}, \mathrm{t}}=\alpha_{0}+\alpha_{1} Q_{i, t}+\alpha_{2} S I Z E_{i, t}+\alpha_{3} L E V_{i, t}+\varepsilon_{i, t}$ & \\
\hline Independent variable & Coefficient & $\mathrm{t}$-value & Significant \\
\hline Intercept & 0.092 & 1.133 & 0.257 \\
$\mathrm{Q}$ & -0.004 & -4.341 & 0.000 \\
SIZE & -0.004 & -1.355 & 0.176 \\
LEV & 0.016 & 0.372 & 0.709 \\
Coefficient of determination & 0.330 & Adjusted coeff. Of deter. & 0.188 \\
f-value & 2.32 & $\mathrm{f}-$-value significant & 0.000 \\
\end{tabular}

Source: calculations of the study.

Table 7. Results of the tests.

\begin{tabular}{cccc}
\hline Test & Value & Sig. & Result \\
\hline F-test Limer & 1.98 & 0.000 & Supports the fixed effects model against panel data \\
Hausman test & 14.39 & 0.008 & Supports the fixed effects model against random effects \\
\hline
\end{tabular}

Source: calculations of study.

Table 8. Results for the second hypothesis.

\begin{tabular}{cccc}
\hline & Model 2: & $\operatorname{CON}_{\mathrm{i}, \mathrm{t}}=\alpha_{0}+\alpha_{1} M B_{i, t}+\alpha_{2} S I Z E_{i, t}+\alpha_{3} L E V_{i, t}+\varepsilon_{i, t}$ & \\
\hline Independent variable & Coefficient & t-value & Sig. \\
\hline Intercept & -0.375 & -1.271 & 0.204 \\
MB & 0.001 & 0.835 & 0.404 \\
SIZE & 0.020 & 1.34 & 0.178 \\
LEV & 0.009 & 0.295 & 0.767 \\
Coefficient of determination & 0.671 & Adjusted coeff. Of deter. & 0.581 \\
f-value & 7.47 & f-value significant & 0.000 \\
\end{tabular}

Source: calculations of the study. 
and control variables. The value of Durbin-Watson test is equal to 2.01. As this value ranges from 1.5 to 2.5, the significance or differences between actual values and the values predicted by the regression model are independent. Obviously, the significance level of $\mathrm{f}$-value $(0.000)$ is $<0.05$; thus, the regression is valid.

\section{Conclusion}

This study examines the relationship between accounting conservatism and market-to-book ratio and Tobin's Q. The quarterly data was tested for 2008 to 2014 at a significance level of 5\%. Basu (1997) model was used to measure conditional conservatism. To evaluate the effect of market-to-book ratio and Tobin's Q on conditional conservatism, these variables were added to Basu's model. According to results of the first hypothesis, there is a significant relationship between accounting conservatism and Tobin's Q at 95\% confidence; thus, the increase in conservatism decreases Tobin's Q and vice versa. Therefore, the hypothesis is confirmed. According to results of the second hypothesis, there is no relationship between accounting conservatism and market-to-book ratio; thus, the hypothesis is rejected. Hemati and Samadi-Largani (2010) indicate a significant relationship between market-to-book ratio and conservative accruals as well as market-to-book ratio and conservative cash, which is inconsistent with results of the present study [10]. Ball and Kothari (2007) used an econometric model to validate Basu's model in measuring conservatism. They showed that Basu's model was unbiased assuming the asymmetric timeliness of earnings [11]. They also used econometric methods to describe analyses of Roychowdhury and Watts (2007) and asserted that the expected negative relationship between market-to-book ratio (MB) and asymmetric timeliness of earnings in measuring conservatism was due to the reflection of changes in market expectations on unidentified growth opportunities in earnings. Econometrically, their analysis well explained the asymmetric timeliness of earnings.

\section{References}

[1] Watts, R.L. (2003) Conservatism in Accounting Part I: Explanations and Implications. Accounting Horizons, 17, 207221. http://dx.doi.org/10.2308/acch.2003.17.3.207

[2] Basu, S. (1997) The Conservatism Principle and the Asymmetric Timelines of Earnings. Journal of Accounting and Economics, 24, 3-37. http://dx.doi.org/10.1016/S0165-4101(97)00014-1

[3] Darrough, M.N. and Stoughton, N.M. (1990) Financial Disclosure Policy in an Entry Game. Journal of Accounting and Economics, 12, 219-243. http://dx.doi.org/10.1016/0165-4101(90)90048-9

[4] Clinch, G. and Verrecchia, R.E. (1997) Competitive Disadvantage and Discretionary Disclosure in Industries. Australian Journal of Management, 22, 125-137. http://dx.doi.org/10.1177/031289629702200201

[5] Gharabaghian, M. (1993) Economy and Trades. RASA, Tehran.

[6] McNichols, M.F., Rajan, M.V. and Reichelstein, S.J. (2014) Conservatism Correction for the Market-to-Book Ratio and Tobin's q. CESifo Working Paper No. 4626 Category 11: Industrial Organization.

[7] Mehrani, K., Vafisani, J. and Halaj, M. (2009) The Relationship between Debt Contracts and Firm Size and Conservatism in Companies Listed in TSE. Accounting and Auditing Studies, 17, 97-112.

[8] Badvarnahandi, Y. (2011) The Relationship between Some Mechanisms of Corporate Governance and Conservatism in Financial Reporting. Accounting Studies.

[9] Roychowdhury, S. and Watts, R.L. (2007) Asymmetric Timeliness of Earnings, Market-to-Book and Conservatism in Financial Reporting. Journal of Accounting and Economics, 44, 2-31. http://dx.doi.org/10.1016/j.jacceco.2006.12.003

[10] Hemati and Samadi-Largani (2010) The Effect of Market to Book Ratio and Conservative Accruals for the Market to Book Ratio Earnings Conservatism Cash Item.

[11] Ball, R., Kothari, S.P. and Nikolaev, V.V. (2013) Econometrics of the Basu Asymmetric Timeliness Coefficient and Accounting Conservatism. http://www.ssrn.com 